\title{
Perancangan Sistem Grid Tie Inverter pada Pembangkit Listrik Tenaga Surya
}

\author{
SITI SAODAH, SRI UTAMI \\ Teknik Konversi Energi Politeknik Negeri Bandung \\ Email : ss_herlina@yahoo.com \\ Received 18 Desember 2018 | Revised 3 Januari 2019 | Accepted 9 April 2019
}

\begin{abstract}
ABSTRAK
Grid Tie Inverter (GTI) merupakan inverter yang digunakan untuk mengubah energi yang dihasilkan panel surya berupa arus searah (DC) menjadi arus bolakbalik (AC). Keluaran dari GTI berupa bentuk gelombang sinusoidal yang masih belum ideal dan mempunyai nilai Total Harmonic Distortion (THD) di atas 3\% serta nilai efisiensi belum mencapai 90\%. Pengurangan nilai THD dan peningkatan efisiensi dapat dilakukan melalui proses kontrol switching pada inverter. Penelitian ini mengusulkan inverter dengan boost converter dua tahap, buck converter dua tahap, rangkaian switching control inverter, $H$-Bridge inverter dan rangkaian $L C$ filter. Teknik switching dari inverter yang diusulkan terdiri dari kombinasi modulasi lebar pulsa sinusoida dan gelombang persegi. Berdasarkan hasil pengujian didapatkan nilai THD sebesar 4,97\%. Terdapat selisih sebesar 1,97\% dari nilai awal perancangan. Untuk efisiensi rata-rata inverter off-grid (tidak terkoneksi dengan PLN) sebesar 89,48\% dan 79,4\% untuk inverter on-grid (terkoneksi dengan PLN).
\end{abstract}

Kata kunci: GTI, boost converter, buck converter, switching control,grid, THD.

\begin{abstract}
Grid Tie Inverter (GTI) is an inverter used to convert energy resulted by solar panels in the form of direct current (DC) to alternating current (AC). The output of GTI is unideal sinusoidal and having Total Harmonic Distortion (THD) above 3\% and efficiency below 90\%. Reducing the THD value and increasing efficiency can be done through switching control process on inverters. This research proposed an inverter using two-stage boost converter, two-stage buck converter, an inverter switching control circuit, H-Bridge inverter and LC filter circuit. The switching technique of the proposed inverter system combined sinusoidal and square wave width modulation. The result showed THD of the proposed system is $4.97 \%$, and still, there is a difference of $1.97 \%$ of the desired value. For average efficiency of off-grid systems (not connected with State Electricity Company/PLN) is $89.48 \%$ and $79.4 \%$ for on-grid systems (connected with PLN).
\end{abstract}

Keywords: GTI, boost converter, buck converter, switching control,grid, THD 


\section{PENDAHULUAN}

Grid tie Inverter (GTI) adalah inverter yang bekerja secara langsung dari panel surya tanpa melalui sumber backup, selain itu juga dapat digunakan secara bersama dengan penyedia jaringan listrik utama Perusahaan Listrik Negara (PLN).

Untuk mendapatkan kinerja Grid Tie Inverter (GTI) yang baik diperlukan daya keluaran dari panel surya yang maksimum dan gelombang keluaran dari Grid Tie Inverter (GTI) harus berbentuk gelombang sinusoidal murni. Panel surya memiliki kelemahan dimana daya keluarannya tergantung kepada kondisi radiasi matahari. Ketika cahaya matahari redup, arus keluaran modul surya bisa drop secara drastis, sehingga daya keluarannya tidak digunakan secara maksimal. Untuk mendapatkan daya keluaran inverterdigunakan Maximum Power Point Tracker (MPPT) dengan topologi Buck-Boost Converter dimana rangkaian tersebut akan memaksa modul surya mengeluarkan daya maksimalnya ketika radiasi matahari tidak maksimal (Amri, 2015) (Utami, 2018) (Utami,S, 2017) (Setyabudy, 2012)

Salah satu kendala penggunaan Grid Tie Inverter (GTI) adalah keluarannya belum berbentuk sinusoidal murni. Performansi keluaran Grid Tie Inverter (GTI) salah satunya direpresentasikan oleh nilai Total Harmonic Distortion (THD). Pemanfaatan teknik switching inverterdiketahui dapat meminimalkan nilai THD inverter. Pembangkitan sinyal sinusoidal telah dilakukan penelitiannya oleh Rashid dan Chakraboty Sajib (Rashid, 2011) (Chakraboty Sajib, 2013) dengan memanfaatkan Pulse Wave Modulation(PWM). Sedangkan Widaringtyas menggunakan sinyal segitiga dan sinyal kotak untuk pembangkitan sinyal sinusoidal (Widaringtyas, 2010).

Dalam penelitian ini dilakukan perancangan sistem inverteryang dapat digunakan sebagai Grid Tie Inverter (GTI) yang dapat digunakan pada Pembangkit Listrik Tenaga Surya (PLTS). Performansi sistem dinilai dari nilai efisiensi dan nilai Total Harmonic Distortion (THD) untuk mengetahui kesesuaian hasil perancangan dengan standar yang berlaku.

\section{METODE PENELITIAN}

\subsection{Panel Surya}

Panel sel surya mengubah intensitas sinar matahari menjadi energi listrik. Panel sel surya menghasilkan arus yang digunakan untuk mengisi baterai. Panel sel surya terdiri dari photovoltaic, yang menghasilkan listrik dari intensitas cahaya, saat intensitas cahaya berkurang (berawan, hujan, mendung) arus listrik yang dihasilkan juga akan berkurang. Dengan menambah panel sel surya (memperluas) berarti menambah konversi tenaga surya. Umumnya panel sel surya dengan ukuran tertentu memberikan hasil tertentu pula. Daya yang dihasilkan oleh panel surya maksimum diukur dengan besaran Wattpeak $(W p)$, yang konversinya terhadap Watthour $(W h)$ tergantung intensitas cahaya matahari yang mengenai permukaan panel (GTI-Series-Inverter User Manual, 2010). Daya yang dikeluarkan oleh panel surya adalah daya panel dikalikan lama penyinaran. Panel surya dapat menghasilkan arus dari tegangan yang berbeda-beda. Grafik kurva $V$ terhadap I pada Gambar 1, menjelaskan keadaan sebuah Sel Surya yang beroperasi secara normal. Sel Surya akan menghasilkan energi maximum jika nilai $V m p$ dan Imp juga maximum. Sedangkan Isc adalah arus listrik maximum pada nilai volt $=$ nol, Isc berbanding langsung dengan tersedianya sinar matahari. Voc adalah volt maximum pada nilai arus nol, Voc naik secara logaritma dengan peningkatan sinar matahari, karakter ini yang memungkinkan sel surya untuk mengisi baterai/accu. 


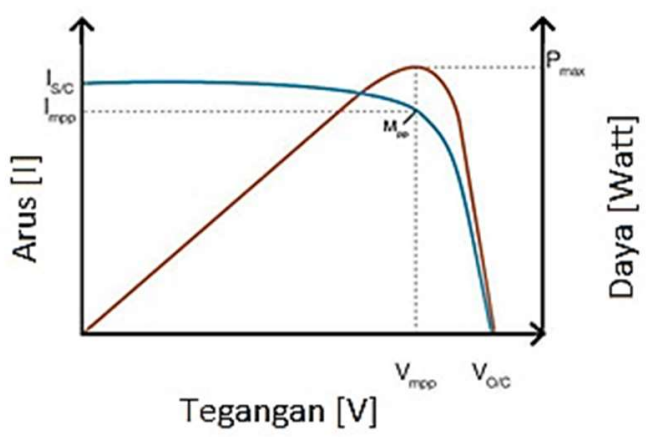

Gambar 1. Kurva V-I Panel Surya

\subsection{Inverter}

Inverter adalah konverter tegangan arus searah (DC) ke tegangan bolak-balik (AC). Fungsi dari sebuah inverter adalah untuk mengubah tegangan masukan DC menjadi tegangan keluaran AC yang simetris dengan besar magnitudo dan frekuensi yang diinginkan. Tegangan keluaran dapat bernilai tetap atau berubah-ubah pada frekuensi tetap atau berubah-ubah. Tegangan keluaran yang berubah-ubah dapat diperoleh dengan memvariasikan tegangan masukan DC dan menjaga penguatan inverter bernilai tetap. Sebaliknya jika tegangan masukan DC tetap dan tidak terkontrol, tegangan keluaran yang berubah-ubah dapat diperoleh dengan memvariasikan penguatan dari inverter. Variasi penguatan inverter biasanya diperoleh dengan menggunakan pengendali Pulse-Width-Modulation (PWM) dan Sinusoidal Pulsa Width Modulation (SPWM) yang ada di dalam inverter (C. L. Chen, 2010) (M. Saghaleini, 2011)

Bentuk gelombang keluaran dari sebuah inverter ideal seharusnya berupa gelombang sinusoidal murni. Namun demikian, bentuk gelombang keluaran inverter tidak berupa gelombang sinusoidal murni dan memuat harmonisa. Harmonisa dapat dieliminasi dengan pemasangan filter dan dengan teknik switching.

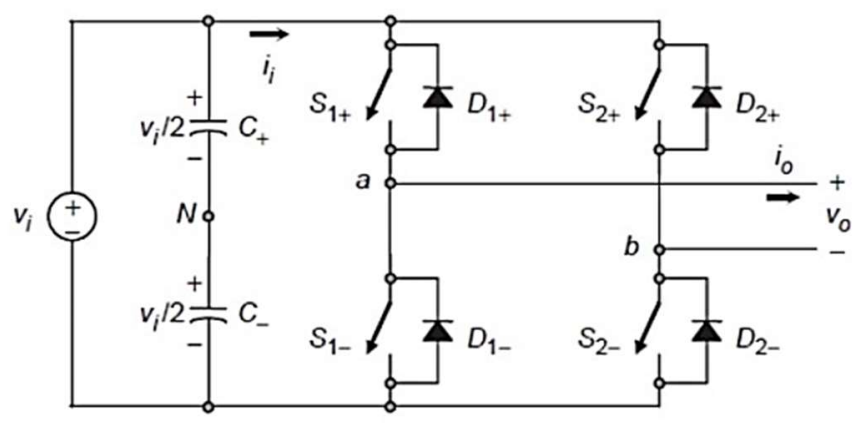

\section{Gambar 2. Skema Pensaklaran Inverter Gelombang Penuh}

Rangkaian invertermemerlukan dua buah kapasitor untuk menghasilkan titik $\mathrm{N}$ agar tegangan pada setiap kapasitor Vi/2 dapat dijaga konstan (Gambar 2). Terdapat dua sisi sakelar, yaitu: sakelar S1+ dan S1- serta S2+ dan S2-. Masing-masing sisi sakelar ini, sakelar S1+ dan S1dan atau S2+ dan S2-, tidak boleh bekerja secara serempak/ simultan, karena akan terjadi 
hubung singkat rangkaian. Kondisi ON dan OFF dari kedua sisi sakelar ditentukan dengan teknik modulasi, dalam hal ini menggunakan prinsip PWM (Seaful Sulun, 2012).

Untuk menghasilkan tegangan keluaran (Vo) satu fasa, terdapat lima kondisi jika sakelar S1+, S1-, S2+, dan S2- dioperasikan sebagaimana ditunjukkan pada Tabel 1 berikut ;

Tabel 1. Lima Kondisi Sakelar Ketika Dioperasikan

\begin{tabular}{|c|c|c|c|c|c|}
\hline $\begin{array}{l}\text { Kondisi } \\
\text { Ke- }\end{array}$ & Kondisi & $V_{\mathrm{aN}}$ & $V_{b N}$ & $V_{0}$ & Komponen yang Aktif \\
\hline 1 & $\mathrm{~S}_{1+} \& \mathrm{~S}_{2 \cdot}$ On dan $\mathrm{S}_{1 \cdot} \& \mathrm{~S}_{2+}$ Off & $V_{/} / 2$ & $-V_{/} / 2$ & $V_{i}$ & $\begin{array}{l}S 1_{+} \& S_{2} . j i k a i_{0}>0 \\
D_{1+} \& D_{2} . j i k a i_{0}<0\end{array}$ \\
\hline 2 & $\mathrm{~S}_{1} \& \mathrm{~S}_{2+}$ On dan $\mathrm{S}_{1+} \& \mathrm{~S}_{2}$. Off & $-V_{/} / 2$ & $V_{V} / 2$ & $-v_{i}$ & $\begin{array}{l}\mathrm{D}_{1-} \& \mathrm{D}_{2+}+\mathrm{jika} \mathrm{i}_{0}>0 \\
\mathrm{~S}_{1} \& \mathrm{~S}_{2+} \mathrm{jjka}^{\mathrm{j}} \mathrm{i}_{0}<0\end{array}$ \\
\hline 3 & $\mathrm{~S}_{1+} \&$ & $V_{1} / 2$ & $V_{/} / 2$ & 0 & $\begin{array}{l}\mathrm{S}_{1+} \& \mathrm{D}_{2+} \mathrm{jika} \mathrm{i}_{0}>0 \\
\mathrm{D}_{1+} \& \mathrm{~S}_{2+} \mathrm{jika \textrm {i } _ { 0 }}<0\end{array}$ \\
\hline 4 & $S_{1} \& \mathrm{~S}$ & $-V_{V} / 2$ & $-V_{/} / 2$ & 0 & $\begin{array}{l}D_{1} \cdot \& S_{2} \cdot j i k a i_{0}>0 \\
S_{1} \& D_{2} \cdot j i k a i_{0}<0\end{array}$ \\
\hline 5 & $S_{1-}-S_{2-}-S_{1+}-S_{2+}$ Off & $\begin{array}{l}-V_{V} / 2 \\
V_{i} / 2\end{array}$ & $\begin{array}{l}V_{/} / 2 \\
-V_{/ 2}\end{array}$ & $\begin{array}{l}-V_{i} \\
V_{i}\end{array}$ & $\begin{array}{l}D_{1-} \& D_{2+} j i k a i_{0}>0 \\
D_{1+} \& D_{2 .} . j i k a i_{0}<0\end{array}$ \\
\hline
\end{tabular}

\subsection{DC - DC Konverter}

Konverter DC-DC adalah rangkaian elektronika daya untuk mengubah suatu masukan tegangan DC menjadi keluaran tegangan DC yang nilai tegangannya bisa lebih besar atau lebih kecil dari tegangan masukannya. Dasar dari DC-DC konverter terdiri dari tiga topologi yaitu buck converter, boost converter, dan buck boost converter.

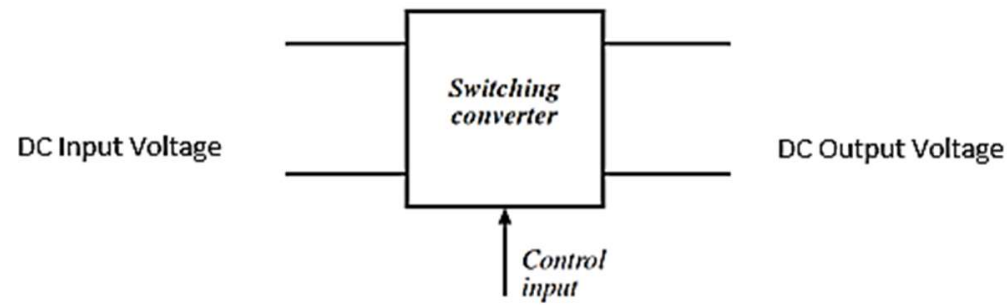

Gambar 3. DC-DC Converter

Buck converter adalah konverter DC-DC dimana tegangan keluarannya lebih kecil dari pada tegangan masukannya (penurun tegangan).

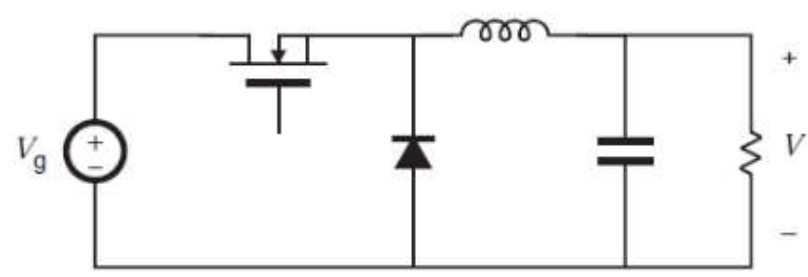

Gambar 4. Rangkaian Buck Converter 
Boost Converter adalah konverter DC-DC dimana tegangan keluarannya lebih besar dari pada tegangan masukannya (penaik tegangan).

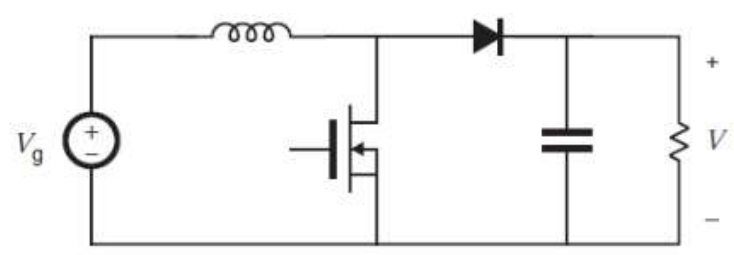

\section{Gambar 5. Rangkaian Boost Converter}

Buck-Boost converter adalah konverter DC-DC dimana tegangan keluarannya dapat diatur lebih kecil atau lebih besar dari pada tegangan masukannya (penurun dan penaik tegangan).

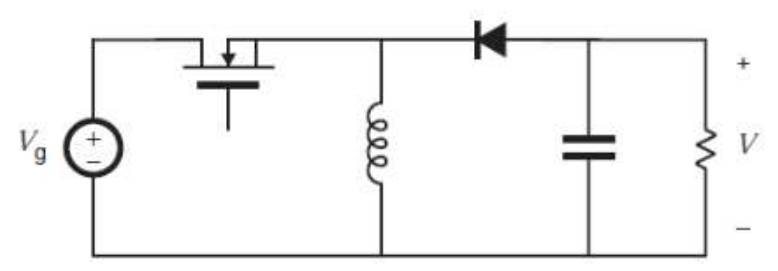

Gambar 6. Rangkaian Buck-Boost Converter

\subsection{Parameter Performa Inverter}

Keluaran inverter masih memuat harmonisa sehingga gelombangnya belum sinusoidal murni. Kualitas dari inverter dapat dianalisis melalui parameter berikut ini ;

Effisensi merupakan perbandingan antara output dengan input. Nilai efisiensi dapat diformulasikan sebagai berikut :

$$
\eta=\frac{\text { Pout }}{\text { Pin }} x 100
$$

Distorsi Harmonisa Total (THD) adalah ukuran kemiripan bentuk antara sebuah gelombang dan komponen fundamentalnya yang didefinisikann oleh Persamaan (2).

$$
T H D=\frac{1}{V_{1}}\left(\sum_{n=2,3 . .}^{\infty} V_{n}^{2}\right)^{1 / 2}
$$

\section{METOdE PENELITIAN DAN PEMBAHASAN}

\subsection{Metode Penelitian}

Metode yang digunakan pada penelitian ini diawali dengan studi literatur,perancangan dan pengembangan teknik switching, simulasi, pengujian hasil perancangan dan pengolahan data hasil pengujian. 


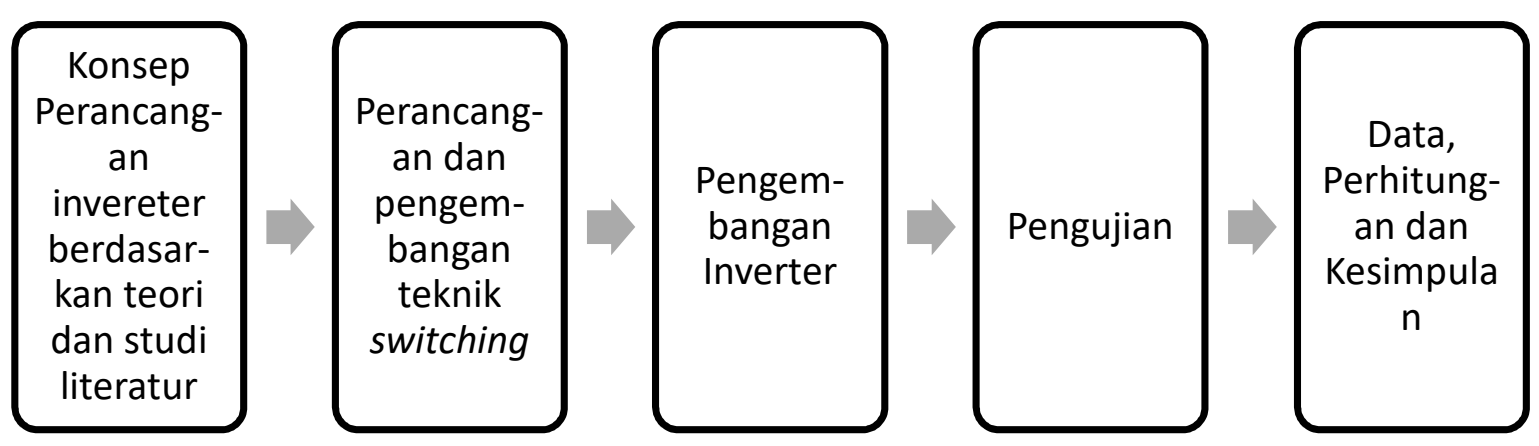

Gambar 7. Langkah-Langkah Perancangan Sistem

Komponen-komponen dalam sistem pembangkit listrik tenaga surya (PLTS) terdiri dari panel surya, inverter, transformator, filter dan beban.

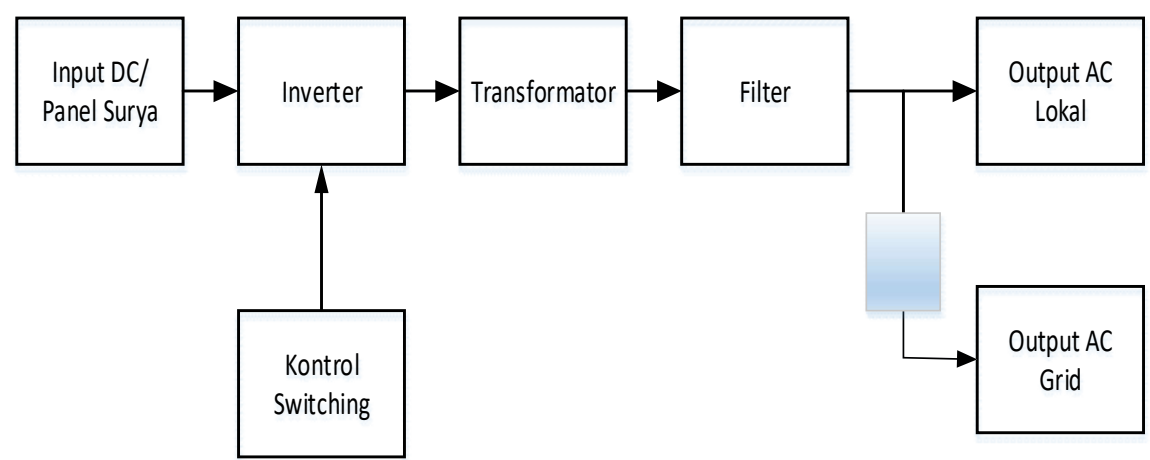

Gambar 8. Blok Diagram Sistem yang Diusulkan

Rangkaian sistem inverter terdiri atas boost converter, rangkaian switching, inverter $H$-bridge, transformator, filter LC dan relay. Inverter yang mengubah tegangan DC rendah menjadi tegangan $A C$ rendah melalui switching dengan frekuensi tinggi $(21 \mathrm{kHz}$ ) lalu tegangan $A C$ tersebut dinaikkan menjadi tegangan $220 \mathrm{~V}$ dengan menggunakan transformator step up dengan frekuensi rendah $(50 \mathrm{~Hz})$. Tabel 2 menunjukkan spesifikasi dari masing-masing komponen.

Tabel 2. Spesifikasi Peralatan

\begin{tabular}{|l|l|c|}
\hline Komponen & \multicolumn{2}{|c|}{ Parameter } \\
\hline Switching Inverter & Gelombang Trigger & 6 Volt \\
\cline { 2 - 3 } & Frekuensi & $21 \mathrm{KHz}$ \\
\cline { 2 - 3 } & Duty Cycle & 0,72 \\
\cline { 2 - 3 } & Tegangan Output & 12 Volt \\
\hline \multirow{5}{*}{ Inverter } & Daya Input DC & 550 Watt \\
\cline { 2 - 3 } & Tegangan Input DC & $21-38$ Volt \\
\cline { 2 - 3 } & Arus Input & $10-22$ Amp \\
\cline { 2 - 3 } & Daya Output AC & 500 Watt \\
\cline { 2 - 3 } & Tegangan Output AC & $180-260$ Volt \\
\cline { 2 - 3 } & Arus Output AC & 2,2 Amp \\
\cline { 2 - 3 } & THD & $93 \%$ \\
\cline { 2 - 3 } & Effisiensi & $94 \%$ \\
\hline
\end{tabular}


Pengujian sistem inverter dilakukan secara dua tahap, tahap pertama melalui simulasi dan tahap kedua pengujian sistem yang dibebani dengan beban resistif. Gambar 9 menunjukkan rangkaian pengujian pembebanan inverter.

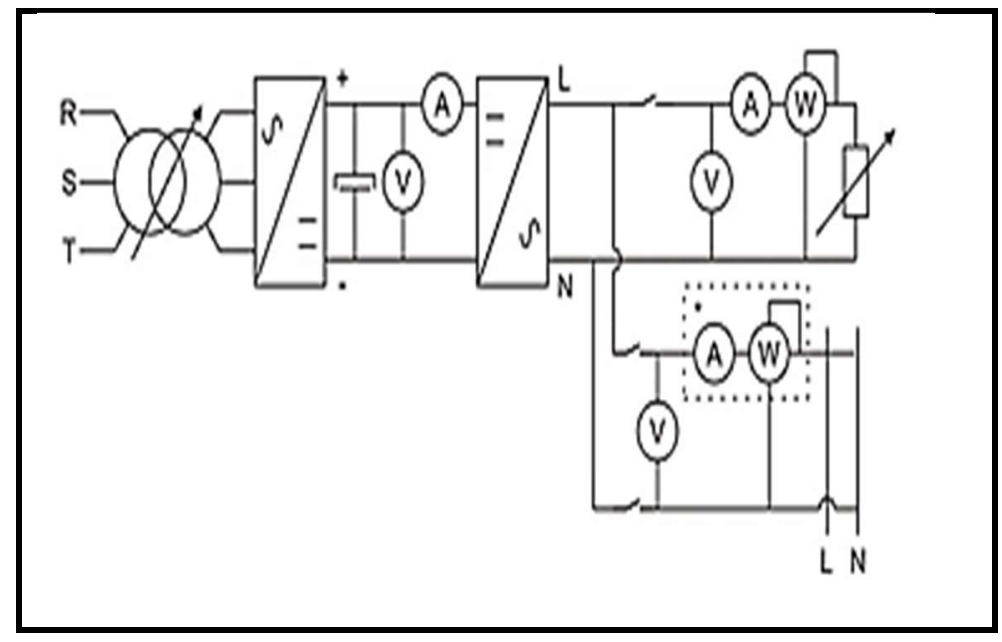

Gambar 9. Rangkaian Pengujian Pembebanan Inverter

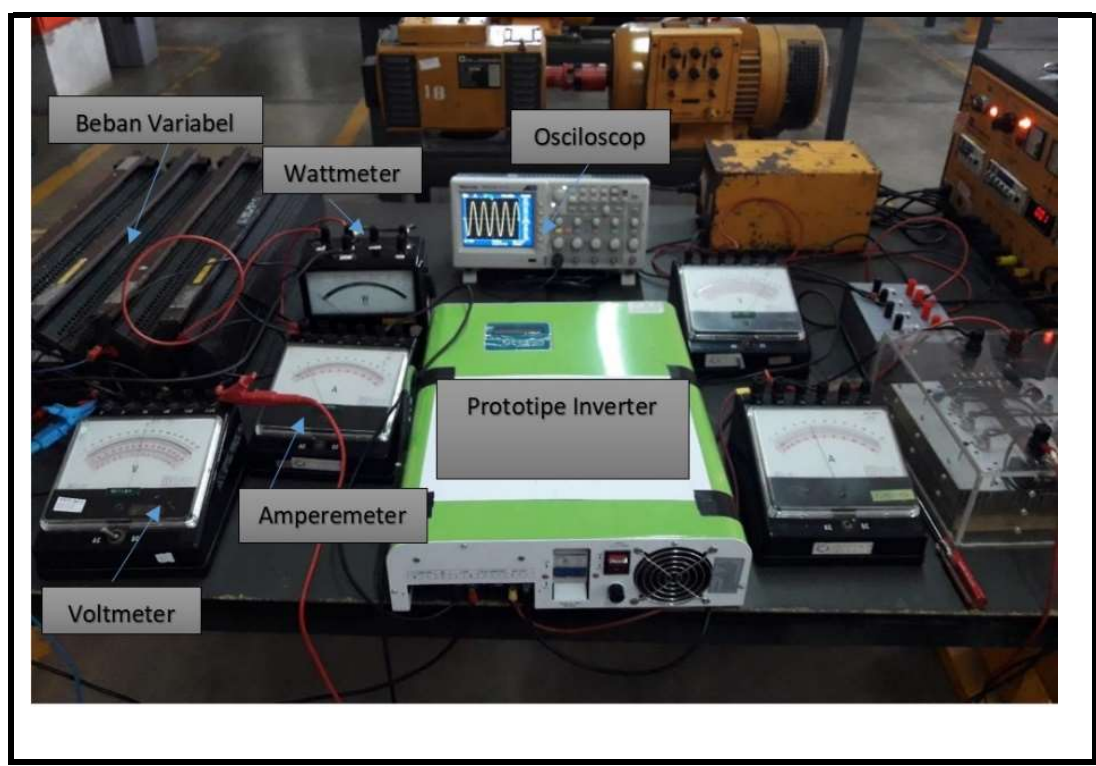

Gambar 10. Realisasi Pengujian Pembebanan Inverter

Gambar 10 menunjukkan realisasi pengujian inverter yang dilakukan dengan menggunakan artificialsumber DC, yang diambil dari sumber PLN 3 phasa yang kemudian dijadikan sumber DC 1 phasa yang besarnya berkisar antara 23 sampai 28 volt. Pengujian ini membutuhkan peralatan diantaranya: autotrafo 3 fasa, rectifier 3 fasa, 1 buah kapasitor polar $2200 \mu \mathrm{F}$, voltmeter 3 buah, amperemeter 3 buah, wattmeter 2 buah dan 3 buah rheostat yang dihubungkan secara seri.

\subsection{Hasil Pengujian dan Pembahasan}

Pengujian inverter bertujuan untuk mengetahui karakteristik dan batasan-batasan dari inverter. 


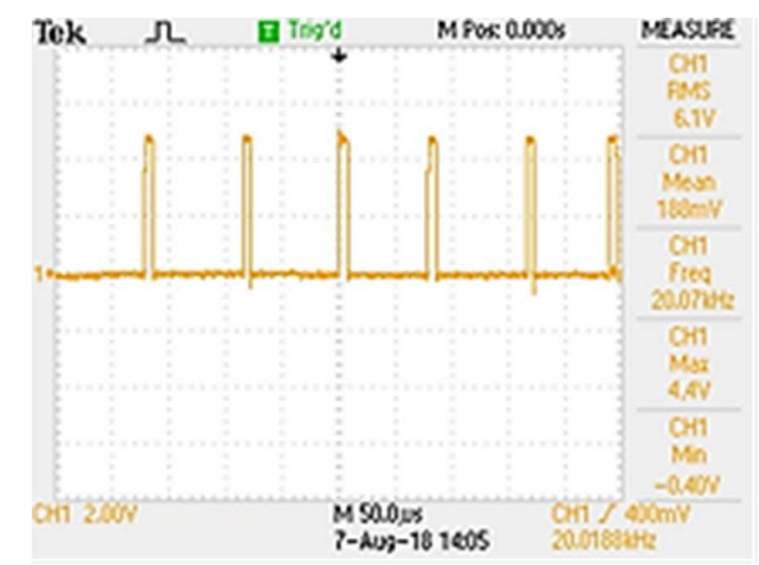

\section{Gambar 11. Gelombang Trigger Inverter}

Gambar 11 menunjukkan gelombang trigger MOSFET berupa gelombang pulsa sebesar 6,1 volt dengan frekuensi $20 \mathrm{kHZ}$. Gelombang ini didapatkan dari rangkaian buck-boost converter 2 tahap yang merupakan rangkaian switching MOSFET. Gelombang tegangan yang dihasilkan sudah sesuai dengan yang dirancang seperti yang ditunjukkan pada Tabel 2.

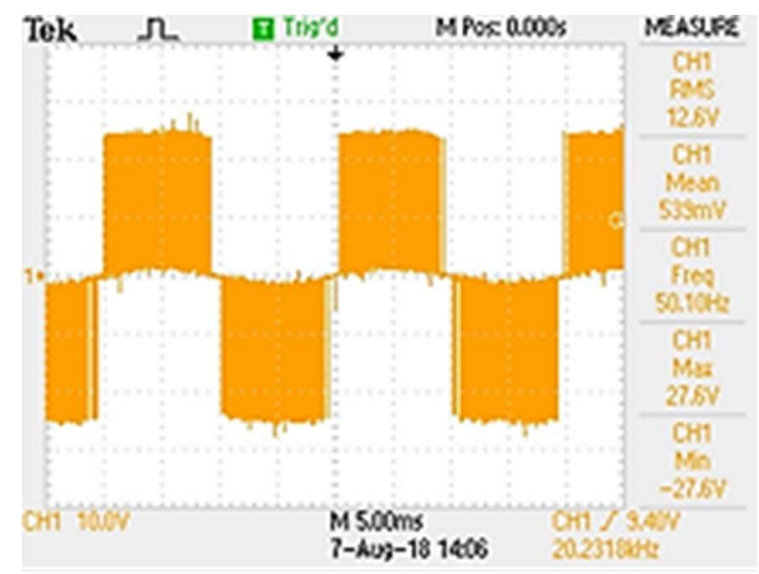

\section{Gambar 12. Gelombang Keluaran Inverter}

Gambar 12 menunjukkan gelombang keluaran inverter yang terdiri dari 4 buah MOSFET yang dipasang secara $H$-Bridge. Besar tegangan keluaran inverter sudah sesuai dengan yang dirancang yaitu sebesar 12,6 Volt AC dengan frekuensi $50 \mathrm{~Hz}$ seperti yang ditunjukkan pada Tabel 2. Gelombang keluaran inverter berbentuk sinusoidal yang masih terdistorsi.

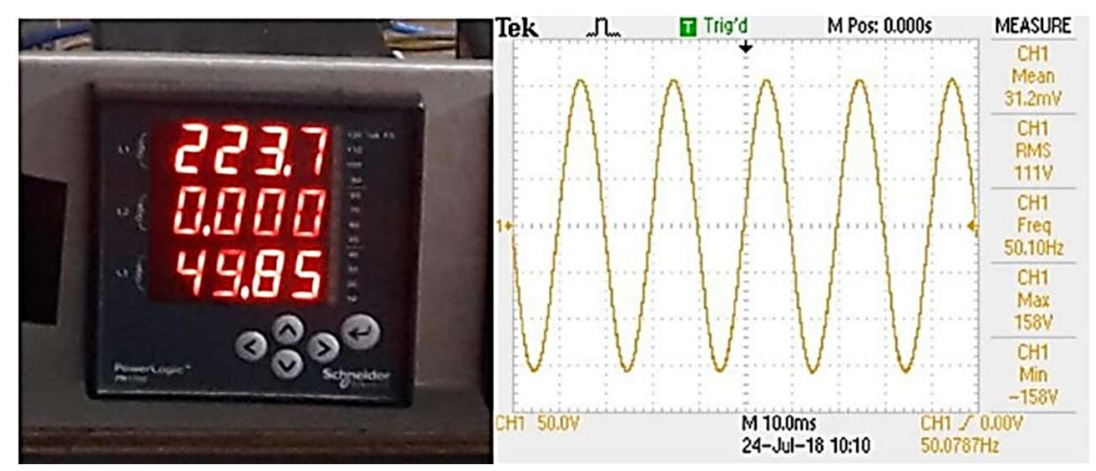

Gambar 13. Besar Tegangan Keluaran Inverter dan Gelombang Keluaran Inverter 
Gambar 13 menunjukkan besar tegangan keluaran inverter sebesar 220 Volt setelah dinaikkan oleh transformator. Dengan pemasangan filter LC, bentuk tegangan keluaran inverter sudah berbentuk sinusoidal.

Pengujian disisi input inverter dilakukan dengan mengukur arus, tegangan dan daya dengan memvariasikan beban resistif (tahanan geser) sebanyak 3 buah yang dipasang secara seri. Kenaikan beban menunjukkan peningkatan nilai resistansi dari $110 \Omega$ sampai dengan $276 \Omega$. Data hasil pengujian input inverter dapat dilihat pada Tabel 3.

\section{Tabel 3. Data Hasil Pengujian Input Inverter}

\begin{tabular}{|c|c|c|c|c|}
\hline \multirow{2}{*}{ No } & \multirow{2}{*}{ Pengujian } & \multicolumn{3}{|c|}{ Masukan } \\
\hline & & Tegangan (V) & $\operatorname{Arus}(A)$ & Daya (W) \\
\hline 1 & Tanpa beban & 28,00 & 1,60 & 44,80 \\
\hline 2 & Beban 1 & 23,00 & 9,60 & 220,80 \\
\hline 3 & Beban 2 & 26,00 & 9,80 & 254,80 \\
\hline 4 & Beban 3 & 28,00 & 11,20 & 313,60 \\
\hline 5 & Beban 4 & 27,00 & 13,80 & 372,60 \\
\hline 6 & Beban 5 & 25,00 & 17,00 & 425,00 \\
\hline 7 & Beban 6 & 28,00 & 17,60 & 492,80 \\
\hline 8 & Beban 7 & 27,00 & 20,20 & 545,40 \\
\hline
\end{tabular}

Arus input inverter (DC) semakin besar dengan bertambahnya beban. Dengan semakin besarnya arus input maka daya input inverter semakin besar. Inverter dibebani sampai mencapai 545.4 Watt.

Tabel 4 menunjukkan hasil pengujian inverter secara berdiri sendiri (off-grid). Tegangan keluaran inverter (output) sudah cukup stabil, nilainya berada dikisaran 218 sampai 221 volt. Arus ouput maksimum mencapai 2 Amp. Daya output inverter mencapai 420 Watt. Walaupun sudah menggunakan filter tetapi nilai THD masih cukup besar. Dari Tabel 4 diketahui bahwa THD tegangan yang dihasilkan oleh inverter berkisar antara $1.23 \%$ sampai $1.32 \%$ dengan nilai rata-rata sebesar $1.27 \%$. Nilai THD arus yang dihasilkan oleh inverter cukup besar, nilainya berkisar antara $2.23 \%$ sampai $4.06 \%$ dengan nilai rata-rata sebesar $3.32 \%$. Pemilihan jenis filteryang tepat sangat diperlukan untuk menurunkan nilai THD, terutama THD arus.

Tabel 4. Data Hasil Pengujian Keluaran Inverter Beban Lokal (Off Grid)

\begin{tabular}{|c|c|c|c|c|c|c|c|}
\hline \multirow[b]{2}{*}{ No } & \multirow[b]{2}{*}{ Pengujian } & \multicolumn{6}{|c|}{ Keluaran } \\
\hline & & Tegangan (V) & Arus (A) & $\begin{array}{c}\text { Cos } \\
\phi\end{array}$ & Daya (W) & THD V (\%) & THD I (\%) \\
\hline 1 & Tanpa beban & 221,30 & 0,00 & - & 0,00 & 0,00 & 0,00 \\
\hline 2 & Beban 1 & 220,70 & 0,80 & 0,91 & 160,00 & 1,23 & 3,19 \\
\hline 3 & Beban 2 & 220,30 & 1,00 & 0,86 & 190,00 & 1,27 & 2,79 \\
\hline 4 & Beban 3 & 220,00 & 1,20 & 0,91 & 240,00 & 1,28 & 3,49 \\
\hline 5 & Beban 4 & 219,90 & 1,40 & 0,94 & 290,00 & 1,28 & 4,06 \\
\hline 6 & Beban 5 & 219,60 & 1,60 & 0,95 & 335,00 & 1,24 & 3,89 \\
\hline 7 & Beban 6 & 219,20 & 1,80 & 0,96 & 380,00 & 1,28 & 3,60 \\
\hline 8 & Beban 7 & 218,90 & 2,00 & 0,96 & 420,00 & 1,32 & 2,23 \\
\hline
\end{tabular}


Tabel 5 menunjukkan hasil pengujian keluaran inverter yang dikoneksikan dengan PLN (ongrid). Tegangan keluaran inverter (output) berada dikisaran 219,6 sampai 221,30 volt. Arus ouput maksimum mencapai 2 Amp. Daya output inverter mencapai 354 Watt. THD tegangan yang dihasilkan oleh inverter berkisar antara $1.15 \%$ sampai $1.27 \%$ dengan nilai rata-rata sebesar $1,08 \%$. Nilai THD arus yang dihasilkan oleh inverter cukup besar, nilainya berkisar antara $2,72 \%$ sampai $12.66 \%$ dengan nilai rata-rata sebesar $4,97 \%$. Nilai THD ini cukup besar walaupun sudah menggunakan filter. Pemilihan jenis filter yang tepat sangat diperlukan untuk menurunkan nilai THD, terutama THD arus.

Tabel 5. Data Hasil Pengujian Keluaran Inverter On-Grid

\begin{tabular}{|c|c|c|c|c|c|c|c|}
\hline \multirow{3}{*}{ No } & \multirow{3}{*}{ Pengujian } & \multicolumn{6}{|c|}{ Keluaran } \\
\hline & & \multicolumn{6}{|c|}{$\operatorname{Cos}$} \\
\hline & & Tegangan (V) & $\operatorname{Arus}(\mathrm{A})$ & $\phi$ & Daya (W) & THD V (\%) & THD I (\%) \\
\hline 1 & Tanpa beban & 221,30 & 0,00 & - & 0,00 & 0,00 & 0,00 \\
\hline 2 & Grid Beban 1 & 221,00 & 0,70 & 0,89 & 135,46 & 1,23 & 12,69 \\
\hline 3 & Grid Beban 2 & 221,30 & 0,90 & 0,85 & 161,53 & 1,27 & 5,42 \\
\hline 4 & Grid Beban 3 & 220,50 & 1,10 & 0,86 & 208,28 & 1,15 & 7,54 \\
\hline 5 & Grid Beban 4 & 220,00 & 1,30 & 0,83 & 243,74 & 1,23 & 2,92 \\
\hline 6 & Grid Beban 5 & 219,90 & 1,50 & 0,84 & 280,93 & 1,19 & 5,77 \\
\hline 7 & Grid Beban 6 & 219,60 & 1,80 & 0,86 & 329,90 & 1,24 & 2,69 \\
\hline 8 & Grid Beban 7 & 219,00 & 2,00 & 0,82 & 354,20 & 1,32 & 2,73 \\
\hline
\end{tabular}

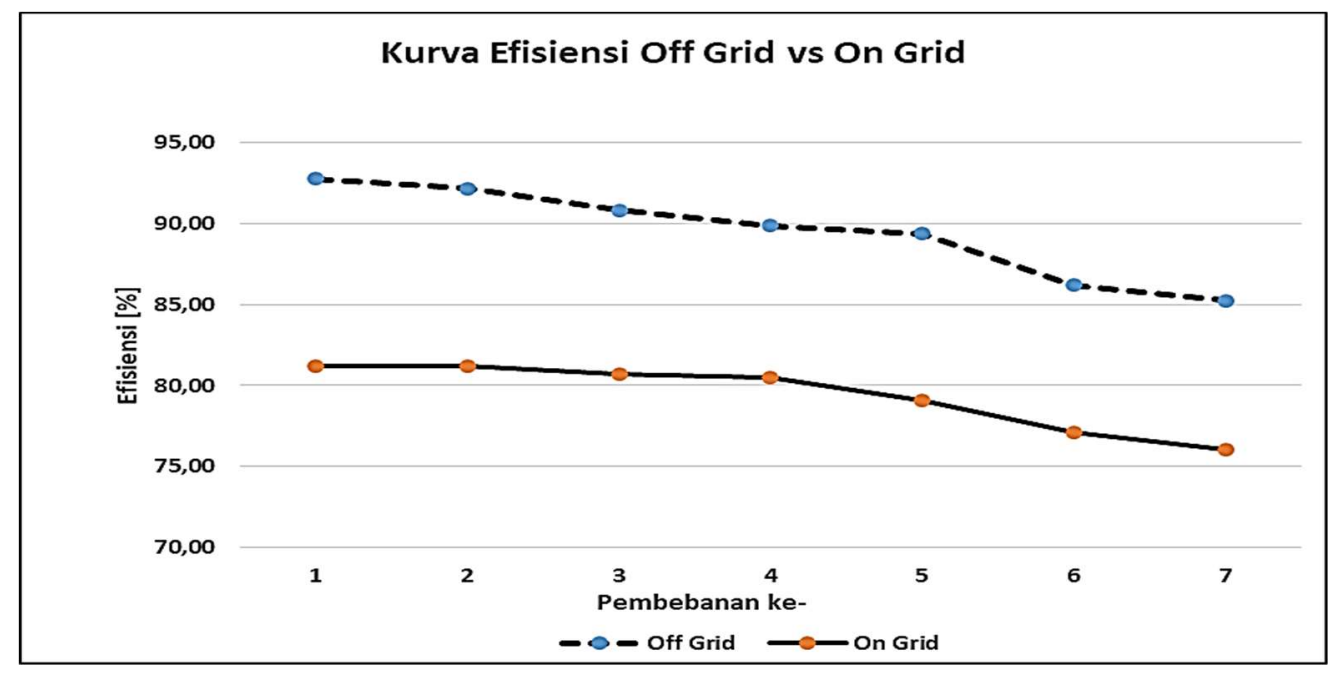

Gambar 14. Kurva efisiensi Terhadap Pembebanan

Gambar 14 menunjukkan hasil pengujian inverter secara off-grid dan on-grid dengan memvariasikan beban yang bersifat resistif. Dari hasil pengujian menunjukkan bahwa nilai efisiensi semakin menurun dengan penambahan beban. Nilai efisiensi inverter yang bekerja off-grid berkisar antara $85,22 \%$ sampai $92,75 \%$, dengan efisiensi rata-rata sebesar $89,48 \%$. Sedangkan Nilai efisiensi inverter yang bekerja on-grid berkisar antara $76,01 \%$ sampai $81,20 \%$, dengan efisiensi rata-rata sebesar $79,40 \%$. Nilai efisiensi inverteryang bekerja secara on-grid lebih kecil dibandingkan dengan inverter off-grid, hal ini disebabkan oleh pengaruh proses sinkronisasi dan faktor daya. Nilai efisiensi ini masih dibawah nilai efisiensi perancangan. Dalam perancangan awal, nilai efisiensi yang diinginkan sebesar $94 \%$. 


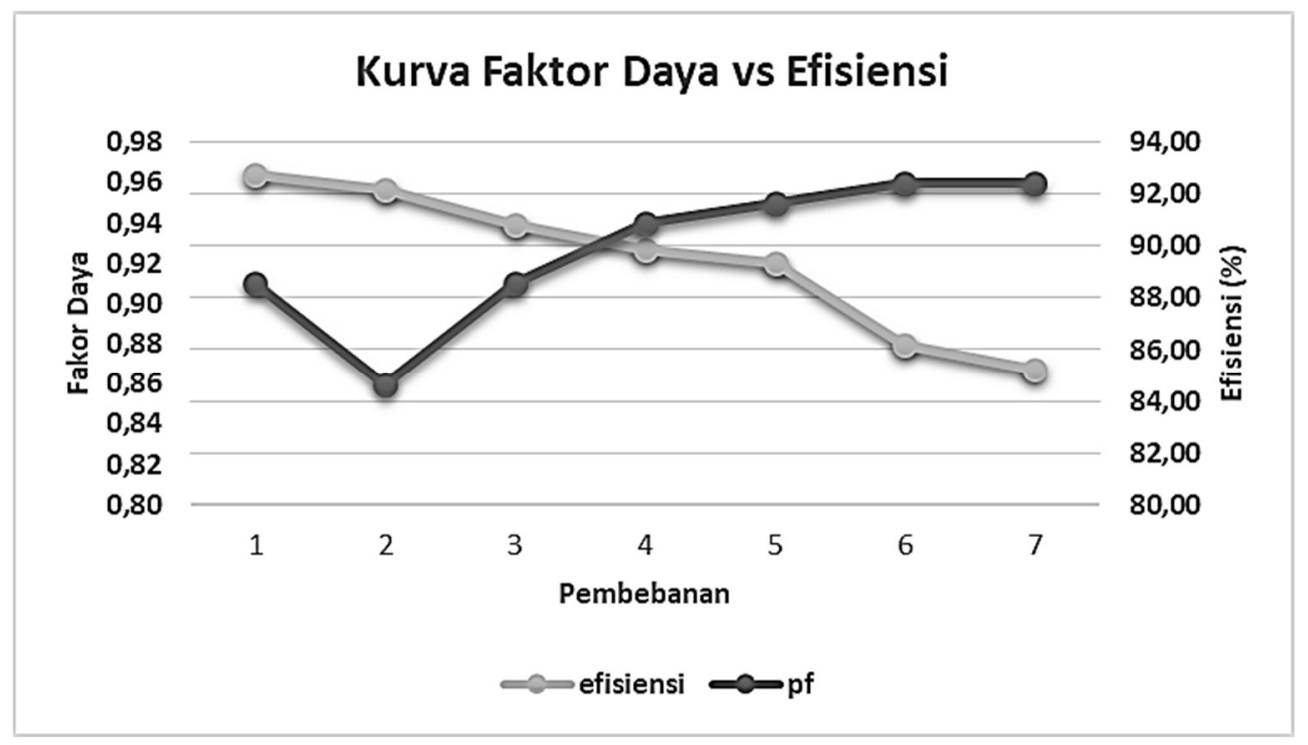

Gambar 15. Kurva Faktor Daya Terhadap Efisiensi

Gambar 15 menunjukkan hasil pengujian dari inverter yang dibebani dengan beban resistif dengan nilai faktor daya (pf) berkisar antara 0,86 sampai 0.96 . Nilai efisiensi berbanding terbalik dengan nilai faktor daya (pf). Ketika faktor daya naik maka nilai efisiensi akan turun, hal ini disebabkan daya output naik.

\section{KESIMPULAN}

Dari hasil pengujian maka dapat ditarik beberapa kesimpulan ;

1. Tegangan keluaran buck-boost converter yang merupakan trigger MOSFET sebesar 6 volt. THD yang dihasilkan pada kondisi off-grid sebesar $1,27 \%$ untuk THD tegangan dan 3,32\% untuk THD arus. THD yang dihasilkan pada kondisi on-grid sebesar 1,08\% untuk THD tegangan dan 4,97\% untuk THD arus.

2. Dari hasil pengujian dengan memvariasikan beban, maka efisiensi rata-rata inverter off-grid sebesar $89 \%$ dan $79 \%$ untuk inverter on-grid. Nilai efisiensi ini masih di bawah nilai yang dirancang yaitu $94 \%$. Oleh karena itu, penelitian akan dilanjutkan dengan mengkombinasikan nilai komponen yang paling efektif untuk menghasilkan nilai efisiensi yang lebih tinggi.

3. Daya input inverter sebesar 540 Watt dan daya output inverter sebesar 420 Watt.

4. Penggunaan inverter off-grid disarankan kurang dari $80 \%$ kapasitasnya sehingga daya input invertertidak akan berada di titik maksimum yang rawan terjadi kerusakan.

5. Penggunaan inverter secara on-grid disarankan kurang dari $70 \%$ kapasitasnya karena apabila lebih dari itu akan beresiko terjadi kerusakan. 


\section{UCAPAN TERIMA KASIH}

Ucapan terima kasih juga untuk Direktorat Riset dan Pengabdian Masyarakat (DRPM) Ristekdikti yang telah membiayai penelitian tahun 2018. Ucapan terima kasih juga disampaikan kepada Unit Penelitian dan Pengabdian Masyarakat (UPPM) Politeknik Negeri Bandung yang telah mendorong, menginisiasi dan mendidik peneliti-peneliti muda untuk berkembang dan mengikuti perkembangan penelitian di Indonesia maupun dunia

\section{DAFTAR RUJUKAN}

Ario Amri.(2015).Perancangan dan Realisasi Solar Charge Controller MPPT dengan Topologi Buck Converter untuk Charger Handphone. Laporan Tugas Akhir, 10 - 35.

C. L. Chen, Y. Wamg, J. S. Lai, Y. S. Lee, D. Martin. (2010). IEEE Transaction on Power Electronic, 25(1), $13-20$.

Chakraboty Sajib. (2013). Design of a Transformer less Grid Tie Photovoltaic Inverter Using Dual Stage Buck and Boost Converters. Department of Electrical and Electronic Engineering: Bangladesh.

GTI-Series-Inverter User Manual. (2010). Mini Solar Grid Connrcted Inverter.

M. Saghaleini, A.K. Kaviani, B. Hadley, B. Mirafzal. (2011). New trends in photovoltaic energy systems. 10th International Conference on Environment and Electrical Engineering (EEEIC), (pp. $10-23)$.

Rashid. Muhamad H. (2011). Power Electronic: Circuits, Devices, and Application (3nd ed). New Jersey: Prentice Hall.

Seaful Sulun. (2012). Analisis Pengaruh Penyambungan Grid Tie Inverter terhadap Harmonisa Sistem Saat Terhubung Beban pada Jaringan TR. Skripsi, $1-25$.

Setyabudy. Setiawan. Hartono. Budiyanto. (2012). Peningkatan Kinerja Grid Inverter pada Jaringan Lustrik Mikro Saat Kondisi Islanding dengan Penambahan Perangkat UPS. Jurnal IImiah Elite Elektro, 3(2), 125 - 131.

Utami,S. (2017). Implementasi Algoritma Perturb and Observe untuk Optimasi Daya Keluaran Solar Cell Menggunakan MPPT di Laboratorium Energi Baru Terbarukan. Jurnal Infotel, $9(1), 5-17$.

Utami,S. Saodah. Pudin. (2018). Penggunaan Algoritma Incremental Conductance pada MPPT dengan Buck Converter untuk Pengujian Indoor dan Outdoor. Jurnal ELKOMIKA, 6(1), $97-109$.

Widaringtyas. Eka, M.,Nurussa'adah. (2017, 27 Juni). Inverter 15 VDC - 220 VAC Berbasis Tenaga Surya untuk Aplikasi Single Ponit Smart Grid. Retrieved from www.sciencedirect.com. 